\title{
Perubahan Pola Pergerakan pada Simpang Kalibanteng akibat Penerapan Manajemen Dua Arah pada Flyover
}

\author{
Y.I. Wicaksono, *Amelia Kusuma Indriastuti, Bambang Riyanto \\ Departemen Teknik Sipil, Fakultas Teknik, Universitas Diponegoro, Semarang \\ *)akindriast@yahoo.com
}

Received: 10 Mei 2017 Revised: 14 Juni 2017 Accepted: 7 Juli 2017

\begin{abstract}
Kalibanteng Intersection is one of primary node in west part of Semarang City. It is a signalized intersection which shaped roundabout. It lies on the truck track from west to east of Java Island, which is crossed over by Flyover Yos Sudarso - Siliwangi and Flyover Sudirman - Siliwangi. Formerly, the flyover is designed for Siliwangi - Yos Sudarso vice versa. The flyover could decrease truck volume from east to west, on the contrary heavy vehicle movement is still overburden Kalibanteng Intersection capacity. On 2018, it is planned that Ahmad Yani Airport access road will be diverted. Thus, it is important to increase Kalibanteng Intersection performance, and accommodate the airport access divertion plan at a time. This research is aimed to identify the existing movement pattern at Kalibanteng Intersection, to evaluate the existing signalized intersection performance, to develop a simulation of two way management on Kalibanteng Flyover, to analyze the movement pattern due to the implementation of two way management on the flyover, and to analyze the signalized intersection due to this management. The results show that the highest movements in Kalibanteng Intersection are the movement from Siliwangi to Yos Sudarso (which is dominated by heavy vehicle) and from Siliwangi to Sudirman (which isi dominated by light vehicle and motorcycle), and will keep on increasing in the future. These movement greatly contribute on intersection performance. This shows that the utilization of the flyover for two-way movement can be considered with mode type limitation. Using two-way flyover, the performance of Kalibanteng signalized intersection will increase.
\end{abstract}

Keywords: Kalibanteng Intersection, movement pattern, two-way management with mode type limitation, signalized intersection performance

\begin{abstract}
Abstrak
Simpang Kalibanteng merupakan simpul utama di Kota Semarang kawasan barat, yang berbentuk bundaran, yang diatur dengan APILL. Simpang ini berada pada jalur kendaraan niaga dari barat ke timur Jawa, yang dilewati Flyover Yos Sudarso - Siliwangi dan Sudirman __Siliwangi (Awalnya flyover ini direncanakan untuk dua arah yaitu Siliwangi - Yos Sudarso dan sebaliknya). Pengoperasian flyover ini mengurangi kendaraan niaga dari timur ke barat, tetapi pada arah sebaliknya, truk masih membebani Simpang Kalibanteng. Tahun 2018, direncanakan ada pengalihan jalan akses Bandara Ahmad Yani. Karenanya, perlu diupayakan peningkatan kinerja Simpang Kalibanteng, sekaligus mengakomodasi pengalihan akses bandara. Penelitian ini bertujuan untuk mengidentifikasi pola pergerakan eksisting di Simpang Kalibanteng dan mengevaluasi kinerjanya, membuat simulasi pergerakan dua arah pada Flyover Kalibanteng, menganalisis perubahan pola pergerakan akibat manajemen dua arah, serta menganalisis kinerja simpang akibat manajemen ini. Hasil analisis menunjukkan bahwa pergerakan tertinggi di Simpang Kalibanteng adalah pergerakan Siliwangi Yos Sudarso (didominasi kendaraan berat) dan Siliwangi - Sudirman (didominasi kendaraan penumpang dan sepeda motor), dan akan terus meningkat di masa mendatang. Pergerakan ini yang memberi kontribusi besar terhadap rendahnya kinerja simpang. Hal ini menunjukkan bahwa pemanfaatan flyover perlu dipertimbangkan untuk pergerakan dua arah dengan pembatasan jenis moda. Dengan pemanfaatan flyover dua arah, kinerja simpang bersinyal pada Simpang Kalibanteng meningkat.
\end{abstract}

Kata-kata kunci: Simpang Kalibanteng, pola pergerakan, manajemen dua arah dengan pembatasan jenis moda, kinerja simpang bersinyal 


\section{Pendahuluan}

Simpang Kalibanteng adalah salah satu simpul utama di Kota Semarang kawasan barat yang menghubungkan akses barat - timur - selatan dan dari bandara. simpang ini berbentuk bundaran, dan berada pada pertemuan enam ruas jalan, yaitu Jalan Yos Sudarso (Jalur Pantura) di Timur Laut, Jalan Sudirman di timur, Jalan Pamularsih di tenggara, Jalan Abdul Rahman Saleh di barat daya, Jalan Siliwangi di Barat, dan Jalan Akses Bandara Ahmad Yani di barat laut.

Jalur ini merupakan perlintasan yang padat kendaraan niaga seperti truk yang mengangkut barang dan layanan jasa dari barat ke timur Jawa ataupun sebaliknya. Berdasarkan data LHR dari Bina Marga, pada tahun 2009 - 2013, jumlah kendaraan niaga yang melintasi Jalur Pantura mencapai rata-rata $26 \%$, dengan proporsi $55 \%$ kendaraan niaga bergerak dari timur ke barat (Hendra \& Adrianto, 2014).

Guna mengurai kemacetan lalu-lintas di kawasan ini, pada tanggal 21 November 2011 mulai dibangun jembatan layang (flyover) di Simpang Kalibanteng. Kajian mengenai flyover di lokasi yang berbeda dilakukan oleh Nuswantoko \& Arthi (2007) di Bandung, Anindita (2012) di Surabaya, serta Wijaya \& Triana (2016) di Bandung.

Jembatan layang sepanjang lebih kurang 720 meter yang menelan biaya sekitar 95 miliar ini merupakan proyek Kementerian Pekerjaan Umum Direktorat Jenderal Bina Marga. Proyek pembangunan tersebut diharapkan mampu mengurangi kepadatan lalu-lintas di kawasan ini. Saat ini, flyover Kalibanteng telah beroperasi selama hampir dua tahun, sejak diresmikan pada tanggal 14 Maret 2014. Flyover ini berbentuk menyerupai huruf "Y", dengan simpulnya di Jalan Arteri Yos Sudarso, Siliwangi dan Sudirman, dengan masing-masing jalur lebarnya sembilan meter dan tinggi jalan layang 4,5 meter. Ilustrasi tentang flyover ini diperlihatkan pada Gambar 1.

Flyover Kalibanteng hanya menghubungkan pergerakan dari timur ke barat, yaitu dari Jalur Pantura (Arteri Yos Sudarso) menuju Jalan Siliwangi dan dari Jalan Jenderal Sudirman menuju Jalan Siliwangi. Sementara, desain awalnya flyover ini direncanakan untuk dua arah yaitu Siliwangi - Yos Sudarso dan sebaliknya.

Berdasarkan Rencana Pengembangan Kawasan Bandara Internasional Ahmad Yani, pada tahun 2018 akan dilakukan pemindahan terminal penumpang, yang semula di selatan runway menjadi di Utara runway. Hal ini perlu ditunjang dengan pengalihan jalan akses masuk dan keluar Bandara Ahmad Yani, dari Jalan Bandara Ahmad Yani dipindah ke Utara melalui Jalan Puri Anjasmoro. Pemindahan jalan akses ini di bawah kewenangan PT. Angkasa Pura, Dinas Bina Marga Provinsi Jawa Tengah dan Pemerintah Provinsi Jawa Tengah. Akibat pengalihan ini, akan terjadi perubahan pola pergerakan di sekitar jalur akses eksisting (Kawasan Kalibanteng). Perubahan jalan akses Bandara Ahmad Yani diperlihatkan dalam Gambar 2.

Pengoperasian fly over ini cukup dapat mengurangi pergerakan kendaraan terutama kendaraan niaga dari arah timur ke barat. Hal ini cukup relevan dengan proporsi pergerakan kendaraan niaga selama ini. Akan tetapi, pada arah sebaliknya, kendaraan besar masih memenuhi lajur-lajur jalan utama, sehingga masih membebani Simpang Kalibanteng yang terletak tepat di bawah Flyover Kalibanteng ini. Untuk itu, perlu dilakukan evaluasi kinerja lalu lintas di Simpang Kalibanteng pasca beroperasinya Flyover Kalibanteng. Evaluasi ini juga mengakomodasi rencana pengalihan akses menuju Bandara Ahmad Yani (semula melewati Kawasan Kalibanteng dialihkan ke Kawasan Puri Anjasmoro).

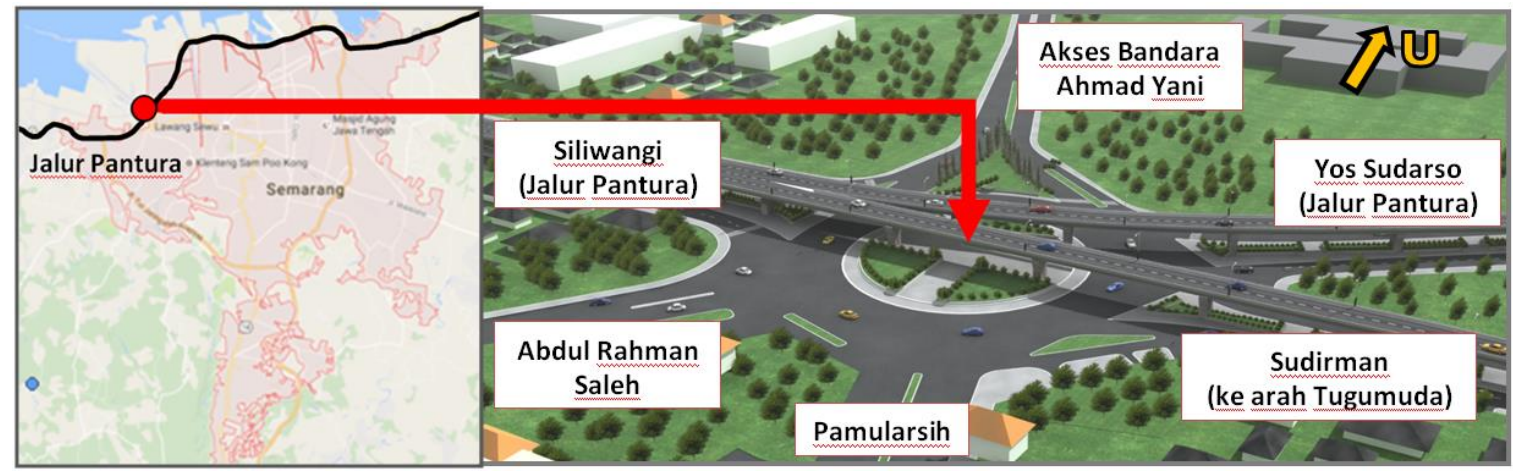

Sumber: Google Maps, 2016; Pambudi, 2013

Gambar 1. Lokasi Simpang Kalibanteng Semarang 


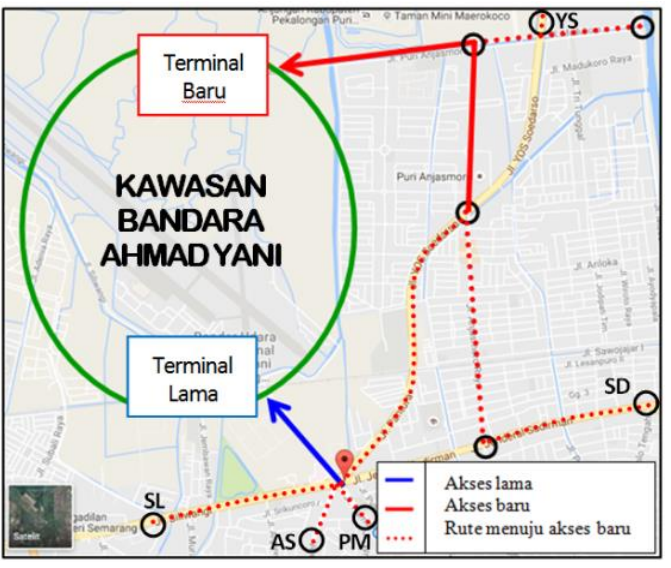

Sumber : google maps, analisis 2016.

\section{Gambar 2. Pengalihan jalan akses Bandara Ahmad Yani}

Guna mengurai kemacetan lalu-lintas di kawasan ini, pada tanggal 21 November 2011 mulai dibangun jembatan layang (flyover) di Simpang Kalibanteng. Kajian mengenai flyover di lokasi yang berbeda dilakukan oleh Nuswantoko \& Arthi (2007) di Bandung, Anindita (2012) di Surabaya, serta Wijaya \& Triana (2016) di Bandung dengan fokus kinerja simpang. Selain itu Poppel (2012) mencoba mengkaji dari sisi dampak penggunaan terhadap polusi. Berbeda dengan Qamaruz-Zaman (2012) yang lebih mencoba mengkaji sisi aktivitas baik dalam menggunakan flyover dan aktivitas di bawah simpang flyover di Kuala Lumpur. Dengan melihat studi terdahulu, maka fokus penelitian ini lebih mendetailkan manajemen simpang di daerah flyover Kalibanteng. Hal tersebut sesuai dengan tujuan penelitian yaitu mengidentifikasi pola pergerakan eksisting di Simpang Kalibanteng Semarang, mengevaluasi kinerjanya, dan membuat simulasi pergerakan dua arah pada Flyover Kalibanteng, dengan menganalisis perubahan pola pergerakan dan kinerja simpang yang terjadi.

\section{Metode Penelitian}

\section{Tahapan penelitian}

Penelitian ini dibagi menjadi tiga tahap sebagai berikut:

1. tahap persiapan, mencakup identifikasi masalah dan survei pendahuluan,
2. tahap pengumpulan data:

a. data sekunder, berupa data LHR dan geometrik, yang diperoleh dari Dinas Bina Marga

b. data primer, berupa data pergerakan keluar dan masuk pada seluruh pendekat simpang, data pergerakan di fly over, pengamatan waktu siklus dan kondisi lingkungan.

3. tahap pengolahan dan analisis data, antara lain:

a. pola pergerakan eksisting.

b. kinerja lalu lintas eksisting, dianalisis dengan MKJI (Bina Marga, 1997), sebagaimana dilakukan dalam beberapa penelitian lainnya (Adrian, 2005; Wikrama, 2011; Sitanggang \& Hariyanto, 2014; Basuki \& Susanto, 2015; Ansusanto \& Tanggu, 2016).

c. simulasi perubahan pengaturan arah pada flyover.

d. perubahan pola pergerakan yang terjadi.

e. kinerja lalu lintas akibat perubahan pola pergerakan, dianalisis dengan MKJI (Bina Marga, 1997).

\section{Studi kasus}

Geometrik keenam pendekat pada Simpang Kalibanteng diperlihatkan dalam Tabel 1. Notasi pendekat diperkenalkan dalam tabel ini untuk dipakai dalam penjelasan selanjutnya. Pada seluruh pendekat simpang diterapkan aturan belok kiri langsung (LTOR), kecuali pada Pendekat Pamularsih. Lajur LTOR pada Pendekat Abdul Rahman Saleh (AS) hanya dipisahkan dengan dengan marka garis lurus, sementara lajur LTOR pada keempat pendekat lainnya dipisahkan dengan pulau (kanalisasi).

Simpang Kalibanteng memang berbentuk bundaran, namun pengaturannya menggunakan APILL (Alat Pemberi Isyarat Lalu Lintas), atau dapat disebut sebagai simpang bersinyal. Perangkat APILL tidak hanya dipasang pada pendekat, tapi juga pada bagian tengah bundaran. Untuk mempermudah pembahasan, lokasi APILL tambahan ini disebut sebagai pendekat A, Pendekat B dan Pendekat C. Gambar 3 memperlihatkan lokasi perangkat APILL ini.

Tabel 1. Geometrik Pendekat pada Simpang Kalibanteng

\begin{tabular}{lccc}
\hline \multicolumn{1}{c}{ Pendekat / notasi } & Lebar masuk efektif $\left(\mathbf{W}_{\mathbf{E}}\right)$ & Lajur LTOR & Median \\
\hline Yos Sudarso / YS & $7,0 \mathrm{~m}$ & ada & ada \\
Sudirman / SD & $7,0 \mathrm{~m}$ & ada & ada \\
Pamularsih / PM & $7,4 \mathrm{~m}$ & tidak ada & ada \\
Abd. Saleh / AS & $8,4 \mathrm{~m}$ & ada & tidak ada \\
Siliwangi / SL & $10,0 \mathrm{~m}$ & ada & ada \\
Bandara A.Yani / AY & $6,9 \mathrm{~m}$ & ada & ada \\
\hline
\end{tabular}

Sumber: Hudoyo, 2006 dan data primer,2016. 


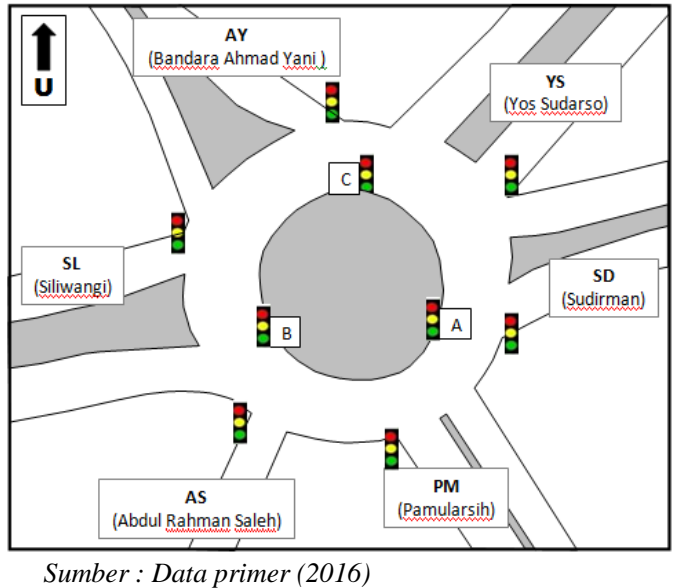

\section{Gambar 3. Lokasi Perangkat APILL di Simpang Kalibanteng}

Pada Simpang Kalibanteng ini, pergerakan pada setiap pendekat diatur menjadi 5 fase dalam sebuah siklus pergantian, sebagai berikut :

1. Fase 1 : Pendekat Siliwangi (SL), A, dan C berhak berjalan, pendekat lainnya berhenti.

2. Fase 2 : Hanya Pendekat Abdul Rahman Saleh (AS), A, B dan C yang berhak berjalan.

3. Fase 3 : Hanya Pendekat Yos Sudarso (YS), A dan B yang berhak berjalan.

4. Fase 4 : Hanya Pendekat Bandara A.Yani (AY), Pamularsih (PM), A dan B yang berhak berjalan.

5. Fase 5 : Hanya Pendekat Sudirman (SD), B dan $\mathrm{C}$ yang berhak berjalan.

Aturan LTOR (belok kiri langsung) diberlakukan pada seluruh pendekat, kecuali Pendekat Pamularsih (PM).

Lamanya waktu siklus pada periode sibuk pagi berkisar 253 detik, sementara pada periode sore berkisar 258 detik. Adapun pembagian durasi waktu hijau, kuning, dan merah dalam satu siklus untuk setiap pendekat diperlihatkan pada Tabel 2.

Tabel 2. Waktu siklus pada periode sibuk pagi pada kondisi eksisting

\begin{tabular}{ccccc}
\hline $\begin{array}{c}\text { Notasi } \\
\text { pendekat }\end{array}$ & $\begin{array}{c}\text { Hijau pada } \\
\text { fase }\end{array}$ & \multicolumn{3}{c}{ Waktu (detik) } \\
\cline { 3 - 5 } HL & 1 & 90 & Kuning & Merah \\
AS & 2 & 32 & 3 & 218 \\
YS & 3 & 25 & 3 & 225 \\
AY & 4 & 48 & 3 & 202 \\
PM & 5 & 33 & 3 & 217 \\
SD & $5,2,3,4$ & 210 & 3 & 40 \\
A & $1,2,3,4,5$ & 153 & 3 & 97 \\
B & $5,1,2$ & 165 & 3 & 85 \\
C & & & &
\end{tabular}

\section{Komponen kinerja simpang}

Komponen kinerja simpang yang ditinjau meliputi arus jenuh (S), kapasitas (C), derajat kejenuhan (DS), panjang antrian $\left(\mathrm{Q}_{\mathrm{L}}\right)$ dan tundaan (D), yang diuraikan sebagai berikut:

1. Arus jenuh (S) adalah arus yang lepas saat hijau. Besarnya arus jenuh sangat tergantung pada kondisi geometrik pendekat (lebar efektif dan kelandaian pendekat), kondisi lingkungan dan hambatan samping, serta pergerakan membelok. Dalam MKJI, hal-hal tersebut diakomodasi dalam nilai arus jenuh dasar dan faktor-faktor penyesuaiannya, dengan uraian sebagai berikut:

a. Untuk pendekat terlindung dengan lebar efektif $\left(\mathrm{W}_{\mathrm{E}}\right)$ tertentu, nilai arus jenuh dasar (So) diperoleh dari persamaan berikut : So = $600 \times \mathrm{W}_{\mathrm{E}}$.

b. Untuk wilayah perkotaan dengan jumlah penduduk berkisar antara satu sampai tiga juta jiwa, faktor penyesuaian akibat ukuran kota (FCS) adalah satu.

c. Untuk kelandaian setiap pendekat yang relatif datar dan tidak adanya kendaraan parkir di simpang, nilai faktor penyesuaian akibat kelandaian (FG) dan parkir (FP) adalah satu.

d. pada bundaran tidak ada pergerakan belok kanan, sehingga nilai faktor penyesuaian akibat pergerakan belok kanan $\left(\mathrm{F}_{\mathrm{RT}}\right)$ adalah satu.

e. Selain Pendekat Pamularsih, kelima pendekat lainnya menerapkan aturan belok kiri langsung (left turn on red/LTOR). Nilai faktor penyesuaian akibat pergerakan belok kanan (FLT) pada pendekat LTOR adalah satu, sementara nilai FLT pada Pendekat Pamularsih=0,99.

f. Arus jenuh yang disesuaikan $(S)=$ So $x$ faktor penyesuaian.

2. Kapasitas pendekat simpang bersinyal merupakan perkalian antara arus jenuh (S) dengan rasio waktu hijau ( $\mathrm{GR}=\frac{g}{c}$ ), di mana $\mathrm{g}$ adalah waktu hijau, sedangkan c adalah waktu siklus (eksisting = 253 detik), yang telah diperlihatkan pada Tabel 2.

3. Derajat Kejenuhan (DS) merupakan perbandingan antara arus (Q, dari Tabel 3) dan kapasitas (C). Nilai DS menjadi salah satu data masukan dalam analisis panjang antrian (QL).

4. Nilai panjang antrian (QL) tergantung pada jumlah antrian (NQ), yang dapat dihitung berdasarkan nilai DS setiap pendekat.

5. Tundaan (D) terdiri tundaan lalu lintas dan tundaan geometrik. Tundaan lalu lintas rata-rata (DT) setiap pendekat dihitung dengan data waktu siklus (c), rasio hijau (GR), derajat kejenuhan (DS), dan kapasitas (C). Sementara, tundaan geometri rata-rata (DG) dihitung dengan 
rasio kendaraan berhenti dan rasio kendaraan berbelok.

\section{Analisis dan Pembahasan}

\section{Pola pergerakan eksisting}

Pergerakan lalu lintas umumnya bersifat fluktuatif. Volume lalu lintas tertinggi untuk total pergerakan dari dan menuju simpang di pagi hari terjadi pada jam 10.00 - 11.00 sebesar $9.505 \mathrm{kend} / \mathrm{jam}$ atau $5.776 \mathrm{smp} / \mathrm{jam}$.

Pola pergerakan eksisting pada simpang ditampilkan dalam bentuk peta garis keinginan (desire line) sebagaimana diperlihatkan dalam Gambar 4. Peta ini berisi garis-garis yang menghubungkan titik asal dan tujuan pergerakan dan memiliki tebal yang berbeda-beda, tergantung pada besarnya pergerakan yang terjadi. Garis yang tebal menunjukkan pergerakan yang dominan. Dengan mengetahui pola pergerakan yang dominan, maka dapat diperoleh gambaran awal mengenai kebutuhan prasarana transportasi yang perlu disiapkan atau dikembangkan di Kawasan Kalibanteng. Pola pergerakan ini sesuai dengan yang disampaikan Hashimoto et al (2016) dan Jiang et al (2016) dimana pola pergerakan eksisting mempengaruhi pola manajemen simpang.

Berdasarkan garis keinginannya, terlihat bahwa terdapat pergerakan dengan jumlah signifikan yang berasal dari Pendekat Siliwangi (SL), terutama yang menuju Pendekat Sudirman (SD), disusul dengan pergerakan yang menuju Pendekat Yos Sudarso (YS). Fakta ini dapat menjadi pendukung atas usulan penggunaan Flyover Kalibanteng yang selama ini hanya satu arah menjadi dua arah pergerakan, baik untuk segmen Siliwangi - Yos Sudarso maupun segmen Siliwangi - Sudirman. Dengan demikian, diharapkan kendaraan jarak jauh dapat langsung melintasi kawasan ini tanpa membebani simpang.

Ditinjau dari komposisi kendaraannya, pergerakan dari Pendekat Siliwangi (SL) menuju Pendekat Yos Sudarso (YS) didominasi oleh kendaraan berat. Sementara, untuk pergerakan dari Pendekat Siliwangi (SL) menuju Pendekat Sudirman (SD) didominasi oleh kendaraan ringan dan sepeda motor.

\section{Kinerja simpang bersinyal eksisting}

Analisis kinerja simpang bersinyal mengacu pada prosedur dalam MKJI (Departemen Pekerjaan Umum, 1997). Adapun parameter yang ditinjau antara lain derajat kejenuhan (DS), panjang antrian $\left(\mathrm{Q}_{\mathrm{L}}\right)$, jumlah kendaraan terhenti $\left(\mathrm{N}_{\mathrm{SV}}\right)$, serta tundaan (D). Untuk dapat menganalisis kinerja simpang bersinyal tersebut, dibutuhkan data masukan berupa arus lalu lintas (Q), arus lalu lintas jenuh (S), dan kapasitas simpang (C). Arus lalu lintas (Q) pada analisis kinerja simpang bersinyal merupakan arus lalu lintas yang masuk/menuju ke Bundaran Kalibanteng (Tabel 3). Apabila terdapat fasilitas LTOR, maka jumlah arus ini dikurangi dengan jumlah pergerakan belok kiri.

Komponen kinerja simpang ini diperlihatkan dalam Tabel 4. Hasil analisis kinerja simpang APILL menunjukkan bahwa hampir semua pendekat memiliki nilai DS kurang dari 0,85 pada saat jam puncak, kecuali Pendekat Siliwangi (SL), sebagaimana diperlihatkan dalam Tabel 4. Tingginya pergerakan di Pendekat Siliwangi (SL) yang menuju ke simpang berdampak pada tingginya nilai DS. Secara teoritis, nilai DS >0,85 sudah menunjukkan kinerja yang sangat buruk. Untuk itu, jumlah pergerakan yang masuk dari Pendekat Siliwangi (SL) perlu dialihkan, supaya beban di pendekat ini dapat berkurang. Dengan demikian, kinerja pada Pendekat Siliwangi (SL) dapat diperbaiki.

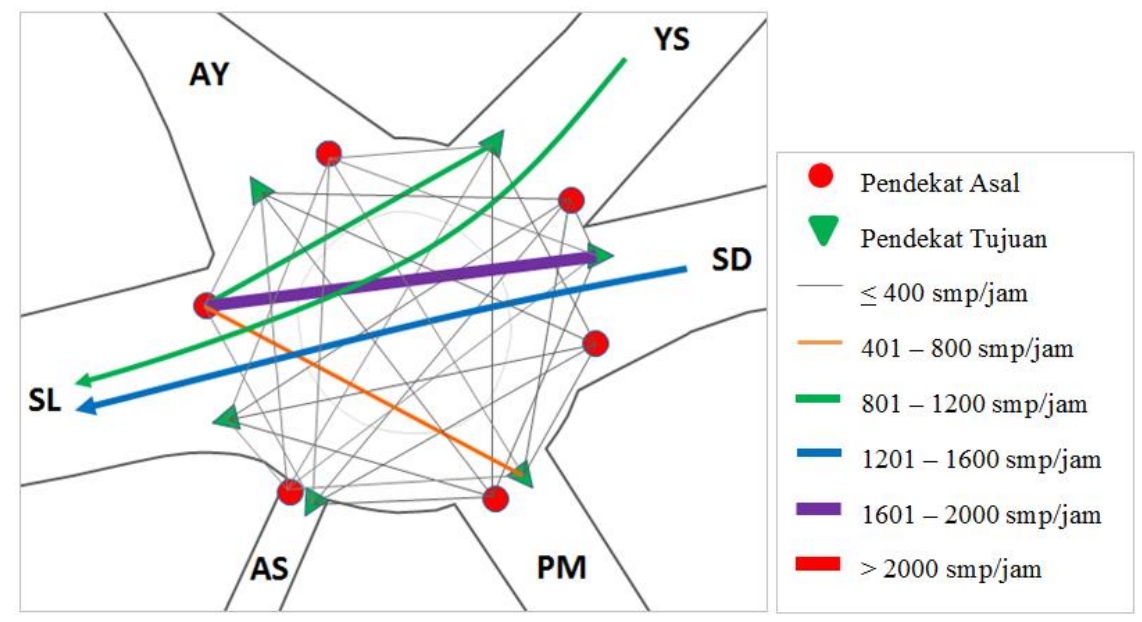

Gambar 4. Pola Pergerakan di Simpang Kalibanteng pada Kondisi Eksisting 
Tingginya nilai DS berpengaruh pada hasil perhitungan jumlah antrian dan panjang antrian. Akibatnya nilai panjang antrian teoritisnya menjadi sangat besar. Nilai ini sesungguhnya kurang sesuai dengan kondisi di lapangan. Antrian yang terjadi pada Pendekat Siliwangi (SL) memang panjang, tapi masih kurang dari $1 \mathrm{~km}$. Hal ini menunjukkan bahwa dibutuhkan penyesuaian dalam MKJI, terutama untuk nilai-nilai referensi yang digunakan sebagai acuan. Hal ini tentunya membutuhkan suatu kajian tersendiri. Dalam penelitian ini, penyesuaian MKJI tidak dilakukan, sehingga nilainilai yang dihasilkan hanya digunakan sebagai indikasi kondisi yang terjadi di lapangan.

\section{Simulasi perubahan pengaturan arah}

1. Pemilihan rute akibat pengalihan akses Bandara Ahmad Yani

Rencana pemindahan jalur akses bandara dari Simpang Kalibanteng ke Kawasan Puri Anjasmoro (PRPP) pada tahun 2018 akan mengakibatkan perubahan pola pergerakan. Faktor-faktor yang mempengaruhi pengguna jalan memilih rute perjalanan adalah jarak tempuh terpendek dan waktu tempuh tercepat menuju lokasi tujuan. Hasil pemilihan rute diperlihatkan dalam Tabel 5. Hasil analisis rute terpendek ini sejalan dengan prinsip efisiensi dalam kinerja simpang (Hashimoto et al., 2016; Jiang et al., 2016; Strauss et al., 2014; Bang et al., 2016).

2. Pola pergerakan baru akibat pengalihan akses Bandara Ahmad Yani (tahun 2018)

Akibat adanya pengalihan akses ini, diperkirakan akan terjadi perubahan pola pergerakan di Kawasan Kalibanteng, sebagaimana diperlihatkan pada Gambar 5. Gambar ini juga sudah mengakomodasi pertumbuhan lalu lintas sebesar $5,28 \% /$ tahun. Secara umum, pola pergerakan tidak berubah secara signifikan, walaupun tentunya tetap ada peningkatan dari segi jumlah pergerakannya. Pergerakan yang dominan masih terlihat pada jalur Siliwangi - Sudirman, disusul Siliwangi - Yos Sudarso, dan pada tahun 2018 bertambah Siliwangi-Pamularsih.

Penambahan volume lalu lintas pada Jalan Yos Sudarso dan Jalan Sudirman akibat pola pergerakan baru dan pertumbuhan lalu lintas ini berkisar $200 \mathrm{smp} / \mathrm{jam}$.

Tabel 3. Arus Lalu Lintas (Q) di Simpang Kalibanteng pada kondisi eksisting

\begin{tabular}{cccc}
\hline Notasi Pendekat & $\begin{array}{c}\text { Arus masuk simpang } \\
\text { (smp/jam) }\end{array}$ & $\begin{array}{c}\text { Arus belok kiri } \\
\text { (smp/jam) }\end{array}$ & $\begin{array}{c}\text { Arus total (Q) } \\
\text { (smp/jam) }\end{array}$ \\
\hline YS & $(1)$ & $(2)$ & $(3)=(1)-(2)$ \\
SD & 189 & 44 & 145 \\
PM & 565 & 125 & 440 \\
AS & 606 & 0 & 606 \\
SL & 437 & 201 & 236 \\
AY & 3491 & 88 & 3403 \\
A & 487 & 13 & 474 \\
B & 45 & 0 & 45 \\
C & 350 & 0 & 350 \\
\hline
\end{tabular}

Tabel 4. Kinerja simpang kalibanteng pada kondisi eksisting

\begin{tabular}{cccccccc}
\hline \multirow{2}{*}{$\begin{array}{c}\text { Notasi } \\
\text { pendekat }\end{array}$} & $\begin{array}{c}\text { Hijau } \\
\text { dalam fase } \\
\text { ke }\end{array}$ & $\begin{array}{c}\text { Arus jenuh } \\
\text { disesuaikan }\end{array}$ & Kapasitas & $\begin{array}{c}\text { Derajat } \\
\text { kejenuhan }\end{array}$ & $\begin{array}{c}\text { Jumlah } \\
\text { antrian }\end{array}$ & $\begin{array}{c}\text { Panjang } \\
\text { antrian }\end{array}$ & $\begin{array}{c}\text { Tundaan } \\
\text { rata-rata }\end{array}$ \\
\cline { 3 - 8 } & Smp/jam hijau & Smp/jam & & Smp & M & Det/smp \\
\hline SL & 1 & 6000 & 2134 & 1.59 & 992 & 1759 & 1209 \\
AS & 2 & 5040 & 637 & 0.37 & 15 & 49 & 105 \\
YS & 3 & 4200 & 415 & 0.35 & 10 & 39 & 110 \\
AY & 4 & 4140 & 785 & 0.60 & 31 & 112 & 98 \\
PM & 4 & 4514 & 856 & 0.71 & 41 & 130 & 102 \\
SD & 5 & 4200 & 548 & 0.80 & 32 & 108 & 120 \\
A & $1,2,3,4$ & 6000 & 4980 & 0.01 & 1 & 5 & 4 \\
B & $2,3,4,5$ & 4800 & 2903 & 0.12 & 10 & 37 & 23 \\
C & $5,2,1$ & 4800 & 3130 & 0.10 & 8 & 29 & 18 \\
\hline
\end{tabular}


3. Kinerja simpang bersinyal akibat pengalihan akses Bandara Ahmad Yani (tahun 2018)

Walaupun tidak terlalu signifikan, perubahan pola pergerakan dan jumlahnya tetap memberikan pengaruh pada kinerja Simpang Kalibanteng. Adapun parameter dan langkah analisis hampir sama dengan analisis kinerja eksisting.

Terkait dengan jumlah fase, pada kondisi eksisting digunakan lima fase yang berdampak pada lamanya waktu siklus di Simpang Kalibanteng. Oleh karena itu, dilakukan optimasi waktu siklus, sehingga diperoleh pengaturannya menjadi tiga fase, dengan waktu siklus 105 detik. Perhitungan arus jenuh, kapasitas, dan derajat kejenuhan Simpang Kalibanteng pasca pengalihan akses bandara diperlihatkan dalam Tabel 6. Perubahan nilai arus jenuh (S) pada Pendekat Pamularsih (PM) dan Siliwangi (SL) disebabkan karena adanya perubahan nilai faktor penyesuaian belok kiri $\left(\mathrm{F}_{\mathrm{LT}}\right)$.

Tabel 5. Hasil simulasi pemilihan rute akibat pengalihan akses bandara

\begin{tabular}{|c|c|c|}
\hline $\begin{array}{c}\text { Asal } \\
\text { Pergerakan }\end{array}$ & Rute Lama & Rute Baru \\
\hline Yos Sudarso & Yos Sudarso - Bundaran Kalibanteng - A.Yani & Yos Sudarso - Puri Anjasmoro \\
\hline Sudirman & Sudirman - Bundaran Kalibanteng - A.Yani & Sudirman - Puri Anjasmoro \\
\hline Pamularsih & Pamularsih - Bundaran Kalibanteng - A.Yani & $\begin{array}{l}\text { Pamularsih - Bundaran Kalibanteng - Yos Sudarso } \\
\text { - Puri Anjasmoro }\end{array}$ \\
\hline Abd.Saleh & Abd. Saleh - Bundaran Kalibanteng - A.Yani & $\begin{array}{l}\text { Abd.Saleh - Bundaran Kalibanteng - Yos Sudarso } \\
\text { - Puri Anjasmoro }\end{array}$ \\
\hline SIliwangi & Siliwangi - A.Yani & $\begin{array}{l}\text { Siliwangi - Bundaran Kalibanteng - Yos Sudarso - } \\
\text { Puri Anjasmoro }\end{array}$ \\
\hline
\end{tabular}

Tabel 6. Arus jenuh, kapasitas, dan derajat kejenuhan Simpang Kalibanteng pasca pengalihan akses bandara (2018)

\begin{tabular}{|c|c|c|c|c|c|c|c|c|c|}
\hline \multirow{3}{*}{$\begin{array}{c}\text { Notasi } \\
\text { pendekat }\end{array}$} & \multirow{3}{*}{$\begin{array}{c}\text { Hijau } \\
\text { dalam } \\
\text { fase ke }\end{array}$} & $\begin{array}{c}\text { Arus } \\
\text { jenuh }\end{array}$ & $\begin{array}{c}\text { Arus lalu } \\
\text { lintas }\end{array}$ & $\begin{array}{c}\text { Waktu } \\
\text { hijau }\end{array}$ & Kapasita & $\begin{array}{c}\text { Derajat } \\
\text { kejenuhan }\end{array}$ & $\begin{array}{c}\text { Jumlah } \\
\text { antrian }\end{array}$ & $\begin{array}{c}\text { Panjang } \\
\text { antrian }\end{array}$ & $\begin{array}{l}\text { Tundaan } \\
\text { rata-rata }\end{array}$ \\
\hline & & $\mathbf{S}$ & $\mathbf{Q}$ & g & $\mathbf{C}$ & DS & $\mathbf{N Q}_{\text {Total }}$ & $\mathbf{Q}_{\mathbf{L}}$ & D \\
\hline & & $\begin{array}{c}\text { smp/ja } \\
\text { m }\end{array}$ & $\begin{array}{c}\text { smp/ja } \\
\text { m }\end{array}$ & Det & $\begin{array}{c}\text { smp/ja } \\
\text { m }\end{array}$ & & smp & $\mathbf{m}$ & det/smp \\
\hline PM & 1 & 4514 & 694 & 56 & 1640 & 0,42 & 22 & 75 & 40 \\
\hline SD & 2 & 4200 & 358 & 56 & 1526 & 0,23 & 11 & 40 & 37 \\
\hline SL & 1.2 & 6000 & 3967 & 112 & 4359 & 0,91 & 141 & 354 & 24 \\
\hline $\mathrm{C}$ & 1.2 & 4800 & 271 & 112 & 3487 & 0,08 & 3 & 13 & 7 \\
\hline YS & 3 & 4200 & 136 & 27 & 739 & 0,18 & 5 & 20 & 57 \\
\hline AS & 3 & 5040 & 271 & 27 & 887 & 0,31 & 10 & 32 & 58 \\
\hline A & 3 & 6000 & 961 & 27 & 1056 & 0,91 & 44 & 113 & 80 \\
\hline B & 3 & 4800 & 571 & 27 & 845 & 0,68 & 23 & 75 & 65 \\
\hline
\end{tabular}
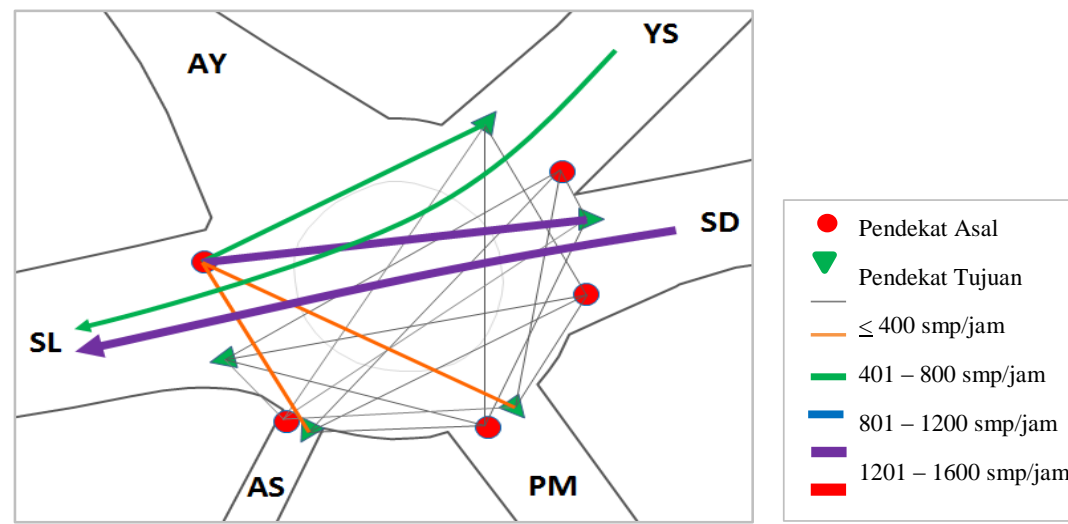

Gambar 5. Pola Pergerakan di Simpang Kalibanteng akibat Pengalihan Akses Bandara Tahun 2018 
4. Penerapan pergerakan dua arah pada flyover Kalibanteng

Penyediaan Flyover Yos Sudarso - Siliwangi dan Sudirman - Siliwangi dua arah dinilai perlu setelah melihat pola pergerakan yang terjadi pasca pengalihan akses bandara, di mana ternyata pergerakan Siliwangi - Sudirman dan Siliwangi Yos Sudarso masih menjadi dua pergerakan yang tertinggi di Kawasan Kalibanteng. Dengan flyover dua arah, diharapkan total arus dari Siliwangi menuju Yos Sudarso maupun Sudirman dapat melewati flyover. Namun demikian, penerapan flyover dua arah ini menuntut adanya penambahan flyover baru yang dapat melayani arah pergerakan yang berlawanan dengan flyover eksisting. Hal ini tentunya membutuhkan biaya yang besar dan waktu yang lama. Sebagai masa transisi, akan disimulasikan beberapa skenario penggunaan flyover dua arah dengan pembatasan jenis moda untuk mengoptimasi kinerja flyover dan simpang saat ini, sebagaimana diperlihatkan dalam Tabel 7.

5. Pola pergerakan baru akibat pengalihan akses Bandara Ahmad Yani dan Penerapan Flyover dua arah

Akibat adanya penerapan flyover dua arah ini, diperkirakan akan terjadi perubahan pola pergerakan yang signifikan di Kawasan Kalibanteng, sebagaimana diperlihatkan pada Gambar 6. Pada skenario I, di mana hanya kendaraan berat yang boleh melintasi flyover, dan seluruh kendaraan lain harus lewat simpang, terlihat adanya ketidakseimbangan sebaran pergerakan dari Siliwangi ke Sudirman dan sebaliknya yang melintasi flyover dengan simpang. Pergerakan yang melintasi flyover sangat kecil sementara yang melewati simpang sangat besar. Hal ini disebabkan karena pergerakan dari Siliwangi ke Sudirman lebih didominasi kendaraan ringan dan sepeda motor. Sementara, pergerakan dari Siliwangi - Yos Sudarso (dan sebaliknya) relatif berimbang antara pergerakan di flyover dan di simpang. Pada skenario II, hanya kendaraan ringan yang diijinkan melintasi flyover. Terlihat pemanfaatan flyover Yos Sudarso - Siliwangi (dan sebaliknya) tidak dapat dioptimalkan, dan cenderung sepi. Hal yang sama juga terlihat pada pola pergerakan dalam skenario III, di mana hanya sepeda motor saja yang boleh lewat flyover. Sementara, flyover Sudirman - Siliwangi (dan sebaliknya) justru menjadi sangat ramai. Hal ini menunjukkan bahwa pergerakan antara kedua pendekat ini didominasi oleh kendaraan ringan dan sepeda motor. Berdasarkan pola pergerakan tersebut, dibuat suatu kombinasi dengan memanfaatkan proporsi kendaraan. Flyover kemudian direncanakan untuk melayani kendaraan dengan proporsi yang besar. Dengan demikian, Flyover Yos Sudarso - Siliwangi dan sebaliknya hanya melayani kendaraan berat, sementara Flyover Sudirman - Siliwangi dan sebaliknya hanya melayani kendaraan ringan. Dengan skenario ini, terlihat bahwa terjadi keseimbangan pergerakan di flyover dan di simpang.

6. Kinerja simpang bersinyal akibat pengalihan akses Bandara Ahmad Yani dan penerapan flyover dua arah

Perubahan pola pergerakan sebagaimana diperlihatkan pada Gambar 6 berdampak signifikan pada kinerja Simpang Kalibanteng. Dengan parameter dan langkah yang sama dengan analisis kinerja simpang dengan penerapan flyover satu arah, perbandingan kinerja dari setiap skenario diperlihatkan pada Tabel 7. Kinerja yang diperbandingkan hanyalah nilai derajat Kejenuhan (DS). Di sini juga diprediksikan besarnya DS lima tahun kemudian (2023).

Tabel 7. Skenario pergerakan dua arah pada flyover Kalibanteng

\begin{tabular}{|c|c|c|}
\hline Sken. & Pergerakan pada flyover & Keterangan \\
\hline I & $\begin{array}{l}\text { Kedua flyover dioperasikan } 2 \text { arah, } \\
\text { khusus untuk HV }\end{array}$ & $\begin{array}{c}\text { Tidak ada HV melintasi simpang dari Pendekat Yos Sudarso } \\
\text { - Siliwangi dan Pendekat Sudirman - Siliwangi, dan } \\
\text { sebaliknya }\end{array}$ \\
\hline II & $\begin{array}{c}\text { Kedua flyover dioperasikan } 2 \text { arah, } \\
\text { khusus untuk LV }\end{array}$ & $\begin{array}{c}\text { Tidak ada LV melintasi simpang dari Pendekat Yos Sudarso } \\
\text { - Siliwangi dan Pendekat Sudirman - Siliwangi, dan } \\
\text { sebaliknya }\end{array}$ \\
\hline III & $\begin{array}{c}\text { Kedua flyover dioperasikan } 2 \text { arah, } \\
\text { khusus untuk MC }\end{array}$ & $\begin{array}{c}\text { Tidak ada MC melintasi simpang dari Pendekat Yos Sudarso } \\
\text { - Siliwangi dan Pendekat Sudirman - Siliwangi, dan } \\
\text { sebaliknya }\end{array}$ \\
\hline IV & $\begin{array}{l}\text { FO Yos Sudarso - Siliwangi } \\
\text { dioperasikan } 2 \text { arah untuk HV, } \\
\text { FO Sudirman - Siliwangi } \\
\text { dioperasikan } 2 \text { arah untuk LV }\end{array}$ & $\begin{array}{c}\text { Tidak ada HV melintasi simpang dari Pendekat Yos Sudarso } \\
\text { - Siliwangi dan tidak ada LV melintasi simpang dari } \\
\text { Pendekat Sudirman - Siliwangi, dan sebaliknya }\end{array}$ \\
\hline & $\mathrm{HV}=$ heavy vehicle/kendaraan berat $: \mathrm{l}$ & $\begin{array}{l}\text { truk sedang, truk besar } \\
\text { umpang, truk kecil, bus kecil } \\
\text { roda dua maupun roda tiga) }\end{array}$ \\
\hline
\end{tabular}


Dengan pola pergerakan sebagaimana telah diperlihatkan sebelumnya (Gambar 6), dapat diprediksikan pada tahun 2018, kinerja simpang bersinyal (bentuk bundaran) untuk keempat skenario masih cukup baik, terutama untuk skenario II dan skenario IV, sebagaimana diperlihatkan pada Tabel 8. Ketidakseimbangan kinerja antara flyover dengan simpang terlihat pada skenario I, II dan III, di mana flyover memikul beban yang sangat sedikit, sementara simpangnya menanggung beban yang cukup besar. Skenario IV menunjukkan adanya keseimbangan pembagian pergerakan, sedemikian sehingga kinerja pada flyover maupun simpang memperlihatkan nilai yang relatif berdekatan. Penerapan skenario IV ini dapat memanfaatkan prasarana yang sudah ada, yaitu flyover, namun masih membutuhkan penambahan rambu, marka, serta perubahan geometrik, terutama pada bagian masuk dan keluar flyover.

Setelah diproyeksi ke lima tahun (tahun 2023), terlihat bahwa hanpir semua terjadi penurunan kinerja yang cukup besar untuk flyover SudirmanSiliwangi dan pada simpang. Bahkan pada skenario II, nilai DS sudah sangat besar. Hal ini menunjukkan bahwa skenario yang diambil hanya dapat bertahan hingga sekitar lima tahun. Oleh karena itu, apabila jumlah pergerakan terus meningkat, akan diperlukan alternatif lain, yaitu penambahan ruas flyover, sehingga pergerakan dari Yos Sudarso ke Siliwangi (dan sebaliknya) untuk kendaraan berat dapat dilayani oleh masing-masing dua lajur per arah. Demikian juga untuk pergerakan kendaraan ringan di flyover Sudirman Siliwangi (dan sebaliknya). Selain pembangunan ruas flyover tambahan, alternatif pembangunan Jalan Lingkar Utara Semarang dan optimasi angkutan umum (dalam hal ini BRT) diharapkan dapat mengurangi beban lalu lintas yang melewati Kawasan Kalibanteng ini. Hal ini sejalan dengan Strauss et al (2014) dan Bang et al (2016) yang menawarkan alternative ruas jalan baru untuk beberapa jenis moda sehingga mempermudah manajemen simpang.

Tabel 8. kinerja simpang bersinyal akibat pengalihan akses Bandara Ahmad Yani dan penerapan flyover dua arah (tahun 2018 dan 2023)

\begin{tabular}{|c|c|c|c|c|c|c|}
\hline \multirow{3}{*}{$\begin{array}{c}\text { Skenario flyover dua arah } \\
\text { dengan pembatasan jenis } \\
\text { moda }\end{array}$} & \multicolumn{6}{|c|}{ derajat kejenuhan (DS) } \\
\hline & \multicolumn{3}{|c|}{$2018(\mathrm{i}=5,28 \%)$} & \multicolumn{3}{|c|}{$2023(\mathrm{i}=5,28 \%)$} \\
\hline & FO YS-SL & FO SD-SL & Simpang & FO YS-SL & FO SD-SL & Simpang \\
\hline $\begin{array}{l}\text { I. Flyover untuk HV } \\
\text { Flo }\end{array}$ & 0,58 & 0,09 & 0,87 & 0,75 & 0,12 & 0,99 \\
\hline II. Flyover untuk LV & 0,24 & 0,75 & 0,77 & 0,31 & 0,97 & 0,89 \\
\hline III. Flyover untuk MC & 0,13 & 0,83 & 0,91 & 0,17 & 1,08 & 1,03 \\
\hline IV. Kombinasi: & & & & & & \\
\hline $\begin{array}{l}\text { Flyover YS-SL untuk HV dan } \\
\text { Flyover SD-SL untuk LV }\end{array}$ & 0,58 & 0,75 & 0,58 & 0,75 & 0,97 & 0,80 \\
\hline $\begin{array}{l}\text { FO YS - SL : Flyor } \\
\text { FO SD - SL : Flyor }\end{array}$ & & & & & & \\
\hline
\end{tabular}

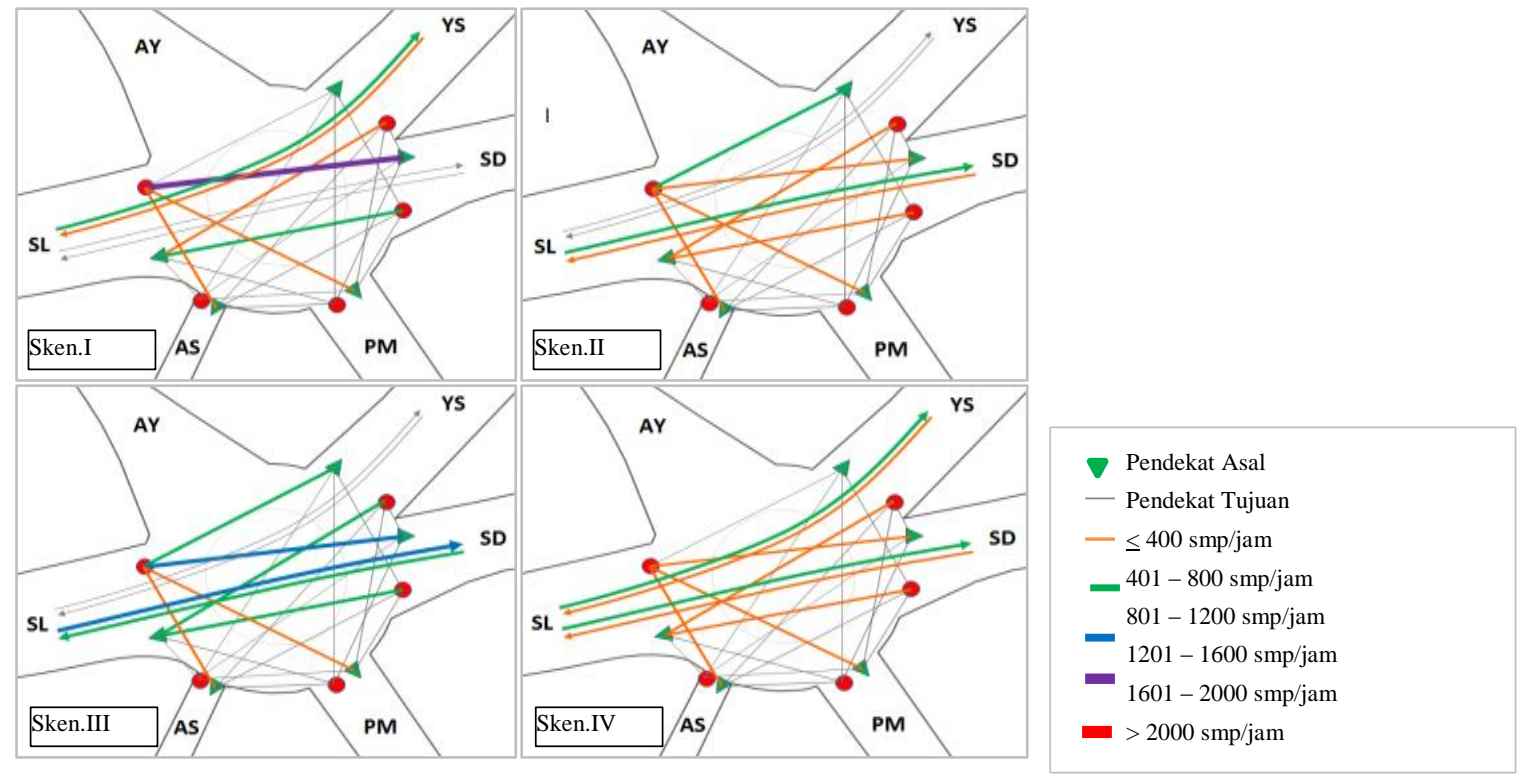

Gambar 6. Pola pergerakan di Simpang Kalibanteng akibat pengalihan akses bandara dan penerapan flyover dua arah (2018) 
Pola pergerakan yang terjadi di Kawasan Kalibanteng pasca beroperasinya Flyover Kalibanteng tahun 2013 masih menunjukkan pergerakan yang sangat tinggi, terutama pada Pendekat Siliwangi yang menuju Pendekat Yos Sudarso dan Pendekat Sudirman. Proporsi kendaraan berat dalam pergerakan antara Siliwangi - Yos Sudarso cukup tinggi, sementara pergerakan antara Siliwangi - Sudirman didominasi oleh kendaraan ringan dan sepeda motor.

Simpang bersinyal Kalibanteng ini diatur dengan waktu siklus real time. Pada pagi hari, lamanya berkisar 253 detik yang terbagi menjadi lima fase. Kinerja simpang bersinyal eksisting menunjukkan kondisi yang sangat buruk terutama pada Pendekat Siliwangi. Optimasi dengan 3 fase memberikan kinerja yang lebih baik.

Untuk mengoptimalkan pemanfaatan flyover dalam peningkatan kinerja simpang dan flyover, diusulkan empat skenario penggunaan flyover dua arah dengan pembatasan jenis moda. Dari keempatnya, skenario empat menghasilkan pola pergerakan dan kinerja lalu lintas yang lebih baik, dengan sebaran pergerakan yang seimbang pada flyover dan simpang. Skenario ini dapat diterapkan dengan penambahan rambu, marka, serta perubahan geometrik, terutama pada bagian masuk dan keluar flyover.

Penerapan skenario ini hanya bertahan selama lima tahun (hingga 2023). Apabila jumlah pergerakan terus meningkat, diperlukan alternatif lain, seperti penambahan ruas flyover, pembangunan Jalan Lingkar Utara Semarang dan optimasi angkutan umum (dalam hal ini BRT).

\section{Kesimpulan}

Perubahan pola pergerakan dan kinerja yang terjadi pasca beroperasinya Flyover Kalibanteng menunjukkan pergerakan yang sangat tinggi. Kinerja simpang bersinyal juga menunjukkan kondisi yang sangat buruk. Dengan perubahan pada jumlah pergerakan lalu lintas yang cukup tinggi, penerapan skenario hanya bertahan selama lima tahun. Analisis perubahan pola pergerakan dengan penerapan menajemen lalu lintas dievaluasi dengan beberapa skenario.

\section{Daftar Pustaka}

Adrian, B. (2005). Analisa Simpang Tugu Muda dan Simpang Lima di Kota Semarang. Tugas Akhir. Program Studi Teknik Sipil, UNIKA Soegijapranata, Semarang.
Anindita, W. (2012). Analisa Lalu Lintas dengan Flyover pada Simpang Jalan Nginden - Jalan Prapen Surabaya. Tugas Akhir. Prodi Teknik Sipil, Institut Teknologi Sepuluh November, Surabaya.

Ansusanto, J. D., \& Tanggu, S. (2016). Analisis Kinerja dan Manajemen pada Simpang dengan Derajat Kejenuhan Tinggi. Jurnal Dinamika Rekayasa, 12(2).

Bang, K., Wahlstedt, J., \& Linse, L. (2016). Methodology for Timing and Impact Analysis of Signalized Intersections. Transportation Research Procedia, 15, 75-86.

Basuki, I., \& Susanto, B. (2015). Kajian Simpang Lima Pojok Beteng Kulon Kota Yogyakarta. Prosiding Konferensi Nasional Teknik Sipil 9, Makassar.

Hashimoto, Y., Gu, Y., Hsu, L. T., Iryo-Asano, M., \& Kamijo, S. (2016). A Probabilistic Model of Pedestrian Crossing Behavior at Signalized Intersections for Connected Vehicles. Transportation Research Part C: Emerging Technologies, 71, 164-181.

Hendra, \& Adrianto, D. (2014). Analisa Pengaruh Muatan Berlebih (Overloading) Kendaraan pada Struktur Perkerasan Rigid terhadap Umur Rencana Perkerasan. Tugas Akhir, Program S1 Lintas Jalur, Jurusan Teknik Sipil, Kerjasama Kementrian Pekerjaan Umum - Universitas Diponegoro, Semarang.

Hudoyo, R. (2006). Efisiensi Rencana Fly Over Kalibanteng Kota Semarang dalam Mengatasi Kemacetan Dari Sisi Pengguna. Tesis, Program Studi Magister Teknik Pembangunan Wilayah dan Kota, Universitas Diponegoro, Semarang.

Jaya Wikrama, A. A. N. A. (2011). Analisis Kinerja Simpang Bersinyal (Studi Kasus Jalan Teuku Umar Barat-Jalan Gunung Salak). Jurnal Ilmiah Teknik Sipil, 15(1).

Jiang, X., Zhang, G., Bai, W., \& Fan, W. (2016). Safety Evaluation of Signalized Intersections with Left-Turn Waiting Area in China. Accident Analysis \& Prevention, 95, 461-469.

Nuswantoko, D., dan Arthi, A. P. (2007). Kajian Kinerja Lalu Lintas Simpang Cileunyi Tanpa dan dengan Flyover. Tugas Akhir, Departemen Teknik Sipil Institut Teknologi Bandung, Bandung.

Pambudi, T. (2013). Proyek Flyover Kalibanteng Semarang, dilihat 16 Februari 2016, <http://pamboedifiles.blogspot.co.id/2012/07/proy ek-fly-over-kalibanteng-semarang.html> 
Qamaruz-Zaman, N., Samadi, Z., \& Azhari, N. F. N. (2012). Opportunity in Leftover Spaces: Activities Under the Flyovers of Kuala Lumpur. Procedia-Social and Behavioral Sciences, 68, 451463.

Sitanggang, L. H. S., \& Hariyanto, J. (2014). Analisis Kinerja Simpang Bersinyal (Studi Kasus: Jalan K.H Wahid Hasyim - Jalan Gajah Mada), Jurnal Teknik Sipil USU,3(2).

Strauss, J., Miranda-Moreno, L. F., \& Morency, P. (2014). Multimodal Injury Risk Analysis of Road Users at Signalized and Non-Signalized Intersections. Accident Analysis \& Prevention, 71, 201-209.
Umum, D. P., \& Marga, D. J. B. (1997). Manual Kapasitas Jalan Indonesia (MKJI). Direktorat Jenderal Bina Marga dan Departemen Pekerjaan Umum, Jakarta.

Van Poppel, M., Panis, L. I., Govarts, E., Van Houtte, J., \& Maenhaut, W. (2012). A Comparative Study of Traffic Related Air Pollution Next to a Motorway and a Motorway Flyover. Atmospheric environment, 60, 132-141.

Wijaya, A., \& Triana, S. (2016). Kinerja Persimpangan Jl. Ibrahim Adjie - Jl. Jakarta dengan Beroperasinya Flyover Jl. Jakarta, Kota Bandung. Reka Racana, 2(2). 